\title{
Book review: \\ Mattheis, F., Raineri, L. \& Russo, A. (2019). Fringe Regionalism. When Peripheries Become Regions. Palgrave Macmillan, 105 p.
}

\author{
A.A. Kornilov \\ Lobachevsky State University of Nizhni Novgorod - National Research University, \\ Nizhni Novgorod, Russian Federation
}

For citation: Kornilov, A.A. (2020). Book review: Mattheis, F., Raineri, L. \& Russo, A. (2019). Fringe Regionalism. When Peripheries Become Regions. Palgrave Macmillan, 105 p. Vestnik RUDN. International Relations, 20 (3), 648 - 651. DOI: 10.22363/2313-0660-2020-20-3-648-651

\section{Рецензия на книгу: Mattheis F., Raineri L., Russo A. Fringe Regionalism. When Peripheries Become Regions. Palgrave Macmillan, 2019. 105 p.}

\author{
А.А. Корнилов \\ Национальный исследовательский Нижегородский государственный университет им. Н.И. Лобачевского, \\ Нижний Новгород, Российская Федерация
}

Для цитирования: Kornilov A.A. Book review: Mattheis F., Raineri L., Russo A. Fringe Regionalism. When Peripheries Become Regions. Palgrave Macmillan, 2019. 105 p. // Вестник Российского университета дружбы народов. Серия: Международные отношения. 2020. Т. 20. № 3. С. 648 -651. DOI: 10.22363/2313-0660-202020-3-648-651

Three authors of the book under review having different countries of origin and job have become united in their attempt to create a fresh look at dynamic development of contemporary regions. Researchers Frank Mattheis of Belgium, Luca Raineri of Italy and Dr. Alessandra Russo of France did not invent anything new from nothing. They simply turned to narratives of certain regions and discovered some new peculiarities in what is called a phenomenon of fringe regionalism.

According to the authors, the concept of fringe regionalism touches base with economic, political, and social realities outside of the realm of formal regional organizations. The European researchers argue that regionalisms emanating outside of national capitals are not necessarily marginalized political, economic or social spaces. On the contrary, their position at the fringes of formal constructions such as nation states, regional organizations or jurisdictions enable these borderlands to establish their own economic, social and political realities and identities. Fringe regionalism, therefore, turns the focus upside down to emphasize how a site's marginal position can be a key feature in its constituting the center of its own region [Mattheis, Raineri, Russo 2019: 2].

(C) Kornilov A.A., 2020

This work is licensed under a Creative Commons Attribution 4.0 International License.

https://creativecommons.org/licenses/by/4.0/ 
This interesting approach inspires the authors so much that they analyze the phenomenon in details and devote almost all the Introductory Remarks to that. They stress that region of specific quality they do research on is usually built on the cross-border practices of non-state actors, informal institutions rooted in states' peripheries and alternative, overlapping sources of legitimacy and identity. Frank Mattheis, Luca Raineri and Alessandra Russo challenge the established concepts and ideas of Theory of International Relations which argue that space and nation-state more than other values play central role in regionbuilding.

This book aims to decenter regionalism by studying allegedly marginal spaces and actors. The ideas and practices of "frontier regionness", "region-building from the peripheries" and the "regionalising potential of the peripheries" are discussed. Areas that are born and developed not in state capitals, but in state peripheries, conventionally portrayed as areas of disconnections and separation [Mattheis, Raineri, Russo 2019: 3]. That is what the authors work with across the text of the monograph and what they have looked empirically at.

Composition of the monograph under review looks very logic and persuasive.

Chapter 1 Introductory Remarks: The Case for Fringe Regionalism [Mattheis, Raineri, Russo 2019: 1 - 4] is devoted to a thorough and careful analysis of what present theories say of regionalism. In the main streams of (neo) realism, liberal institutionalism and constructivism, we see that the primacy of nation states as basic actors remains unquestioned. States in these schools of thought are conceived as units that can be studied in isolation. Along with that federalism paves the way for an idea - although a heavily institutionalized one - of regional space, but federations are still thought to consist of territorially-defined states. Functionalism also suggests a kind of spatiality that is not a priori territorial. The authors conclude that it seems difficult to grasp the dynamics of region-building in borderlands using such frames.

Fringe regionalisms after the detailed analysis of the theory of New Regionalism Approach and some related concepts emerge at two critical junctures within regional spaces. Firstly, they denote the translation between the overarching structures of regional possibilities and the practices enacted by regional actors in borderlands. Secondly, they occupy a key role in representations of regional space in the sense that they embody the counter-imaginaries deployed in opposition to the prevailing conception of space imposed by regional organizations. Acting as junctures, fringe regionalisms open up arenas for negotiation processes involving reciprocal relations between spatial practices, imaginaries and social modes, serving as a means of appropriation for creating, shaping and dominating regional spaces from the margins [Mattheis, Raineri, Russo 2019: 8-15, 18].

In the Chapter 2, Producing Regional Spaces from the Margins: Fringe Regionalism: A Conceptual Proposal to Recalibrate the Study of Regions [Mattheis, Raineri, Russo 2019: 7-38], the researchers aim to emphasize the presence of specific places that provide for the physical infrastructure needed to strengthen interactional dynamics and micro-regional connections, places such as markets, cross-roads and corridors.

It leads to certain non-classic generalizations that not nation-state, not regional policies of great power and not even transnational industries play crucial role in region-building. It turns out that it is trans-border partnership and cooperation, movements of migrants, goods, arms and money are able to form a new regional atmosphere and change a seemingly marginalized territory to a very important and pivotal in many senses area.

Chapter 3 The Practice of Fringe Regionalism: Evidence from the Caucasus and the Sahara [Mattheis, Raineri, Russo 2019: 3976] possibly represents to our mind the most winning part of the text. This chapter is a purely empirical part of the study when Frank Mattheis, Luca Raineri and Alessandra Russo weigh practices of fringe regions and do that with facts and arguments. Here, obviously facts prove and support theory and ideas of fringe phenomenon. This is even more so that the Sahara Desert and the Caucasus have been selected like different areas for the case study. The former is mainly the wilderness territory while the latter is the mountainous one. 
In opinion of the authors, both the Sahara Desert and the Caucasus seem to embody all the defining characteristics of buffer areas or disconnectors: as desert and mountain, the conditions they embody are seen from the outside as a serious obstacle or long-term challenge to governance. Both the Sahara Desert and the Caucasus have usually been framed not as centers but as borderlands.

In the Sahara, cross-border interactions, identities and practices constitute the most significant connective tissue of region-building from the peripheries: shadow regionalizing infrastructures emerge largely in contrast with the "institutional" representation of the Sahara that has traditionally been issued by the regional organizations operating there.

In the Caucasus, in sharp contrast regionbuilding from the peripheries has been activated and de-activated at different times and has acquired a political value of othering, conveying connotations of contestation and emancipation. The authors refer to attempts of non-recognized or partly recognized states like Southern Ossetia and Abkhazia to identify themselves in the complex international relations of today.

As practiced identities, the Sahara and the Caucasus reflect key elements of fringe regionalisms. Identity in these cases emerges from an overlap between an inclusive belonging to the desert or mountains of the regional space and an exclusive marginal position vis-a-vis formal state actors. This identity has the capacity to blend with some reference points, such as religion, and to supersede others, such as nationality or ethnicity. A cross-border identity of the fringes allows actors to resist external attempts to "divide et impera". The porous borders of this identity in spatial terms create space for transgressions and a gradual fading of one element into the other, instead of establishing sharp lines [Mattheis,
Raineri, Russo 2019: 40-41, 70]. Nevertheless, the authors recognize the trend of nation-states involvement and deep influence on the fringe areas, the phenomenon that occurs time and again. Even more interesting are the thoughts of the three researchers about identities of the fringe regions. Forming identity represents a difficult task in changing, hostile and war-torn environment.

Chapter 4, Towards a Wider Application of Fringe Regionalism: Comparisons and Transfers [Mattheis, Raineri, Russo 2019: 77-94], summarizes the study. According to the authors, fringe regionalism offers bridges to synthesise a broader understanding of regionalism as a social process that can be initiated by both centers and peripheries and is likely to generate a reaction on the other side.

Fringe regionalism that is analyzed in the book should not be considered a concept whose applicability it limited to the Global South. The authors stress that independentist movements in Europe suggest that the current national containers of several states are also contested, including say Austria, Cyprus, Kosovo, Spain and the United Kingdom. However, fringe regionalism is only partly applicable to separatism that occurs predominantly inside a state and does not have a cross-border, regional scope. Hence, fringe regionalism is more likely to be found in the Balkans than in Corsica [Mattheis, Raineri, Russo 2019: 86].

Being followers of the pluralistic ontology, Frank Mattheis, Luca Raineri and Alessandra Russo do not exclude previous concepts of regionalism and research approaches like somewhat imperfect. On the contrary, the analysis albeit limited to the Sahara and the Caucasus they have made invites many scholars in regionalism to update the debates of essence and refresh images of areas in the world of 2020s. This is especially true when peripheries become regions.

Received / Поступила в редакцию: 17.02.2020

Accepted / Принята к публикации: 03.03.2020

\section{References / Библиографический список}

Mattheis, F., Raineri, L. \& Russo, A. (2019). Fringe Regionalism. When Peripheries Become Regions. Palgrave Macmillan. 
About the author: Kornilov Alexander Alekseyevich — PhD in History, Dr. of Sc. (History), Head, Chair of Region Studies of Foreign Countries and Local History, Institute of International Relations and World History, Lobachevsky State University of Nizhni Novgorod - National Research University (e-mail: kornilov@imomi.unn.ru).

Сведения об авторе: Корнилов Александр Алексеевич - доктор исторических наук, профессор, заведующий кафедрой зарубежного регионоведения и локальной истории Института международных отношений и мировой истории Национального исследовательского Нижегородского государственного университета им. Н.И. Лобачевского (e-mail: kornilov@imomi.unn.ru). 